\title{
Review \\ Prevalence of Neural Autoantibodies in Epilepsy of Unknown Etiology: Systematic Review and Meta-Analysis
}

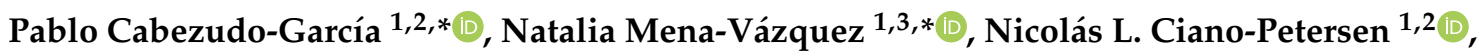

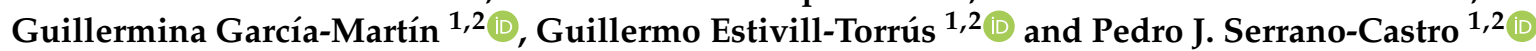 \\ 1 Instituto de Investigación Biomédica de Málaga-IBIMA, 29010 Málaga, Spain; \\ lundahl151@gmail.com (N.L.C.-P.); guillerminagmartin@gmail.com (G.G.-M.); \\ estivill.guillermo@gmail.com (G.E.-T.); pedro.serrano.c@gmail.com (P.J.S.-C.) \\ 2 Unidad de Gestión Clínica de Neurociencias, Hospital Regional Universitario de Málaga, 29010 Málaga, Spain \\ 3 Unidad de Gestión Clínica de Reumatología, Hospital Regional Universitario de Málaga, 29010 Málaga, Spain \\ * Correspondence: pablocabezudo@gmail.com (P.C.-G.); nataliamenavazquez@gmail.com (N.M.-V.)
}

\section{check for}

updates

Citation: Cabezudo-García, P.; Mena-Vázquez, N.; Ciano-Petersen, N.L.; García-Martín, G.;

Estivill-Torrús, G.; Serrano-Castro, P.J. Prevalence of Neural Autoantibodies in Epilepsy of Unknown Etiology: Systematic Review and Meta-Analysis. Brain Sci. 2021, 11, 392. https://doi.org/10.3390/ brainsci11030392

Academic Editor: Giovanni Assenza

Received: 6 February 2021

Accepted: 16 March 2021

Published: 19 March 2021

Publisher's Note: MDPI stays neutral with regard to jurisdictional claims in published maps and institutional affiliations.

Copyright: (c) 2021 by the authors. Licensee MDPI, Basel, Switzerland. This article is an open access article distributed under the terms and conditions of the Creative Commons Attribution (CC BY) license (https:/ / creativecommons.org/licenses/by/ $4.0 /)$.

\begin{abstract}
Background: The prevalence of neural autoantibodies in epilepsy of unknown etiology varies among studies. We aimed to conduct a systematic review and meta-analysis to determine the pooled global prevalence and the prevalence for each antibody. Methods: A systematic search was conducted for studies that included prospectively patients $\geq 16$ years old with epilepsy of unknown etiology and systematically determined neural autoantibodies. A meta-analysis was undertaken to estimate pooled prevalence in total patients with a positive result for at least one neural autoantibody in serum and/or cerebrospinal fluid (CSF) and for each autoantibody. Results: Ten of the eleven studies that met the inclusion criteria and a total of 1302 patients with epilepsy of unknown etiology were included in themeta-analysis. The global pooled prevalence (IC95\%) was 7.6\% (4.6-11.2) in a total of 82 patients with a positive result for any neural autoantibody. None of the controls available in the studies had a positive result. Individual pooled prevalence for each autoantibody was: glycine receptor (GlyR) (3.2\%), glutamic acid decarboxylase (GAD) (1.9\%), $N$-methyl-D-aspartate receptor (NMDAR) (1.8\%), leucine-rich glioma inactivated-1 protein (LGI1) (1.1\%), contactin-2-associated protein (CASPR2) $(0.6 \%)$ and onconeuronal $(0.2 \%)$. Conclusions: The pooled prevalence of neural autoantibodies in patients with epilepsy of unknown etiology is small but not irrelevant. None of the controls had a positive result. There was high heterogeneity among studies. In the future, a homogeneous protocol for testing neural autoantibodies is recommended.
\end{abstract}

Keywords: epilepsy; autoimmune epilepsy; antibodies; autoantibodies; neural autoantibodies; prevalence

\section{Introduction}

Epileptic seizures are one of the most frequent clinical presentations of autoimmune encephalitis [1], and in some cases, it may be the only symptom [2]. Immune epilepsy was firstly included in the ILAE Seizure Classification in 2017 [3], defined as patients with evidence of immune-mediated inflammatory disease in the central nervous system. This evidence is based on MRI and cerebrospinal fluid (CSF) findings, clinical response to immunotherapy, and the presence of neural autoantibodies in serum or CSF [4].

In recent publications, many experts have considered that not all seizures triggered by immune damage to the brain should be considered as immune epilepsy [2] since epilepsy is understood as a chronic process [5]. With this in mind, they suggest two different concepts [6]: "acute symptomatic seizures secondary to autoimmune encephalitis" and "autoimmune-associated epilepsy". The former consider cases in which immune encephalitis with positive neural surface antibodies presents with symptomatic seizures but reaches long-term seizure freedom with immune-targeted therapy [7]; the latter would account for those with antibodies targeting intracellular antigens such as glutamic acid decarboxylase (GAD) and onconeural protein antibodies, in which immunotherapy is 
frequently ineffective as a result of neural death and permanent brain damage [8]. In any case, being able to differentiate this in clinical practice is sometimes difficult, since some cases of autoimmune encephalitis associated with neural surface autoantibodies present as a "forme fruste" with drug-resistant seizures being their only manifestation, or at least the only apparent manifestation, being similar to the chronic course of "autoimmuneassociated epilepsy" [6]. Also, patients harboring neural autoantibodies can present as new-onset epilepsy lacking other features of autoimmune encephalitis and reaching a favorable outcome without the need for immunotherapy [9].

Nevertheless, hypothetical autoimmune pathogenesis may exist in patients diagnosed with epilepsy of unknown etiology and could imply a new therapeutic approach with immune-targeted therapies, for example, in patients with drug-resistant epilepsy. Taking this into account, many studies have attempted to appraise the existence of different neural autoantibodies in series of patients with epilepsy of unknown etiology [10-13], others have also tried to characterize the features of those patients with positive antibodies [14-17], and even some of them have attempted to validate predictive models for neural-specific autoantibody status [18-20]. All those studies presented variable methodologies and results; therefore, we aim to conduct a systematic review of the literature and meta-analysis to identify those studies that performed a systematic approach for the detection of neural autoantibodies in patients with epilepsy of unknown etiology, and analyze its global prevalence as well as the individual prevalence of each autoantibody.

\section{Materials and Methods}

A systematic review was conducted of studies that related to the research question.

\subsection{Study Identification and Selection}

A systematic search was carried out in MEDLINE and Embase until 26 January 2021 using the following MeSH and free text terms: "epilepsy", "seizure", "autoantibody", "autoantibodies", "antibody", and "antibodies". It was restricted to the English language. In Embase, only articles were included (Supplementary Materials). The review protocol followed the declaration of Preferred Reporting Items for Systematic Reviews and MetaAnalyses (PRISMA) [21] and was registered in PROSPERO (CRD42020214838). A free secondary search was also conducted in MEDLINE database with the terms "epilepsy" and "autoantibody" or "antibody" and in the reference lists of selected articles. The search was performed by two researchers (P.C.-G. and N.M.-V.) who independently reviewed article titles and abstracts.

All types of studies were considered for inclusion except conference abstracts, case or cases series reports, and narrative reviews. Patients 16 years or older diagnosed with epilepsy according to the most recent ILAE definition (defined as at least two unprovoked seizures occurring $>24 \mathrm{~h}$ apart orone unprovoked seizure and a probability of at least $60 \%$ of further seizures occurring over the next 10 years) [5] and unknown etiology (or cryptogenic) were included for the analysis. Patients with hippocampal sclerosis were not excluded in the absence of classical risk factors such as febrile seizures, central nervous systeminfection, and birth trauma. We excluded studies performed on pre-selected epilepsy sub-groups (except for adults, new-onset epilepsy, focal epilepsy, hippocampal sclerosis, and drugresistant epilepsy). Studies that included patients with a prior diagnosis of encephalitis or studies including, exclusively, patients with suspicion of encephalitis before antibody testing were also excluded. Also, studies and patients with retrospective recruitment were excluded.

According to the type of intervention, inclusion criteria were as follows: studies in which systematic determination of neuronal autoantibodies in serum and/or CSF was carried out with a positive/negative result (following the method and criteria used in each of the studies). Studies and results regarding the determination of autoantibodies against uncharacterized antigens and GluR3 were excluded due to lack of specificity [22]. Detection of autoantibodies targeting uncharacterized antigens against the voltage-gated 
potassium channel-complex (VGKC complex) but without the presence of leucine-rich glioma inactivated-1 protein (LGI1) or contactin-2-associated protein (CASPR2) autoantibodies were excluded [23]. Regarding glutamic acid decarboxylase (GAD) autoantibodies, only high titters in serum/plasma or an intrathecal synthesis were considered positive. Serum/plasma titters of GAD antibodies considered high for each different method were: radioimmunoassay $(\mathrm{RIA})>1000 \mathrm{U} / \mathrm{mL}$ or $20 \mathrm{nmol} / \mathrm{L}$; ELISA $>10000$ $\mathrm{IU} / \mathrm{mL}$; immunoprecipitation assay (IPA) $>100 \mathrm{nmol} / \mathrm{L}$; positive result in immunoblot; positive result in immunofluorescence (IF) using immunohistochemistry (IHC) or cellbased assay (CBA) $[18,24,25]$. Positive results for onconeuronal antibodies different from anti-Hu (anti-neuronal nuclear antibody, type 1 (ANNA-1), Ri (anti-neuronal nuclear antibody, type 2 (ANNA-2)), anti-neuronal nuclear antibody type 3 (ANNA-3), Ma-1/Ma-2, CV2 or anti-collapsing response-mediator protein-5 (CRMP5), amphiphysin, Purkinje cell cytoplasmic antibody, Type 2 (PCA2), and Purkinje cell cytoplasmic antibody, type $\operatorname{Tr}$ (PCA $\mathrm{Tr})$, antibodies were not considered due to lack of clinically validated association with autoimmune epilepsy [4]. Positive results of control groups (if available) of the different studies were included to calculate risk difference.

The main outcome was global pooled prevalence, measured as the number (\%) of patients with a positive result for at least one neural autoantibody in serum/plasma and/or CSF. The following neural autoantibodies were considered based on their reported association with autoimmune seizures and epilepsy and the frequency of its determination in the literature [4]: high titter GAD, onconeuronal antibodies, $N$-methyl-D-aspartate receptor (NMDAR), amino-3-hydroxy-5-methyl-4-isoxazolepropionic acid receptor (AMPAR) 1 and 2 (AMPAR1/AMPAR2), CASPR2, LGI1, gamma-aminobutyric acid (GABA) A and B receptor (GABAAR, GABABR), and glycine receptor (GlyR). Secondary outcomes were as follows: pooled prevalence of individual antibodies, recorded as the number (\%) of patients with a positive result for a specific neural autoantibody.

\subsection{Data Extraction and Bias Evaluation}

The whole text was read in articles whose titles or abstracts met the inclusion criteria. The failure of any eligibility criterion was sufficient to exclude a study. Two reviewers (P.C.G. and N.M.-V.) extracted the data from the documents, using an ad-hoc data sheet to record study variables (Supplementary Table S1). The level of the evidence was assessed using Scottish Intercollegiate Guidelines Network (SIGN) grading system [26]. Disagreement between reviewers on the inclusion/exclusion of studies was solved by consensus or with the assistance of a third reviewer (P.J.S.-C.).

\subsection{Data Synthesis and Analysis}

A random-effect model (restricted maximum likelihood) was chosen to estimate the global pooled prevalence rate, with a $95 \%$ confidence interval (CI) calculated as an effect measure for all outcomes. The risk differences were used to compared cases and controls. According to the Cochrane review guidelines [27], the pooled prevalence for individual antibodies by the random-effects model (DerSimonian and Laird method) was chosen if severe heterogeneity was present at I2 $>50 \%$, otherwise, the fixed-effects model was adopted (Mantel-Haenszel method). The $95 \%$ CI, I2 as a measure for heterogeneity, and the Egger's and Begg's test as a measure for publication bias were calculated for each analyzed group.

\section{Results}

\subsection{Search}

The literature searches initially retrieved 12,403 studies from which 2817 were excluded as duplicates, 9554 were excluded after reading the title and abstract, and 21 were excluded after reading the whole article (Supplementary Table S2). Therefore, 11 articles met the selection criteria (Figure 1). A total of 1361 patients with epilepsy of unknown etiol- 
ogy and at least one autoantibody tested in serum or CSF were included, and 503 controls were identified. Finally, 1302 patients from ten studies were included in the meta-analysis.

\section{PRISMA PRISM 2009 Flow Diagram}

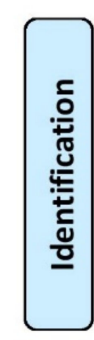

Records identified through database searching $(n=12403)$

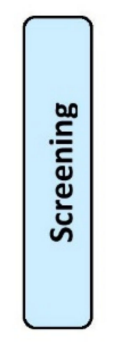

Records after duplicates removed $(n=9586)$
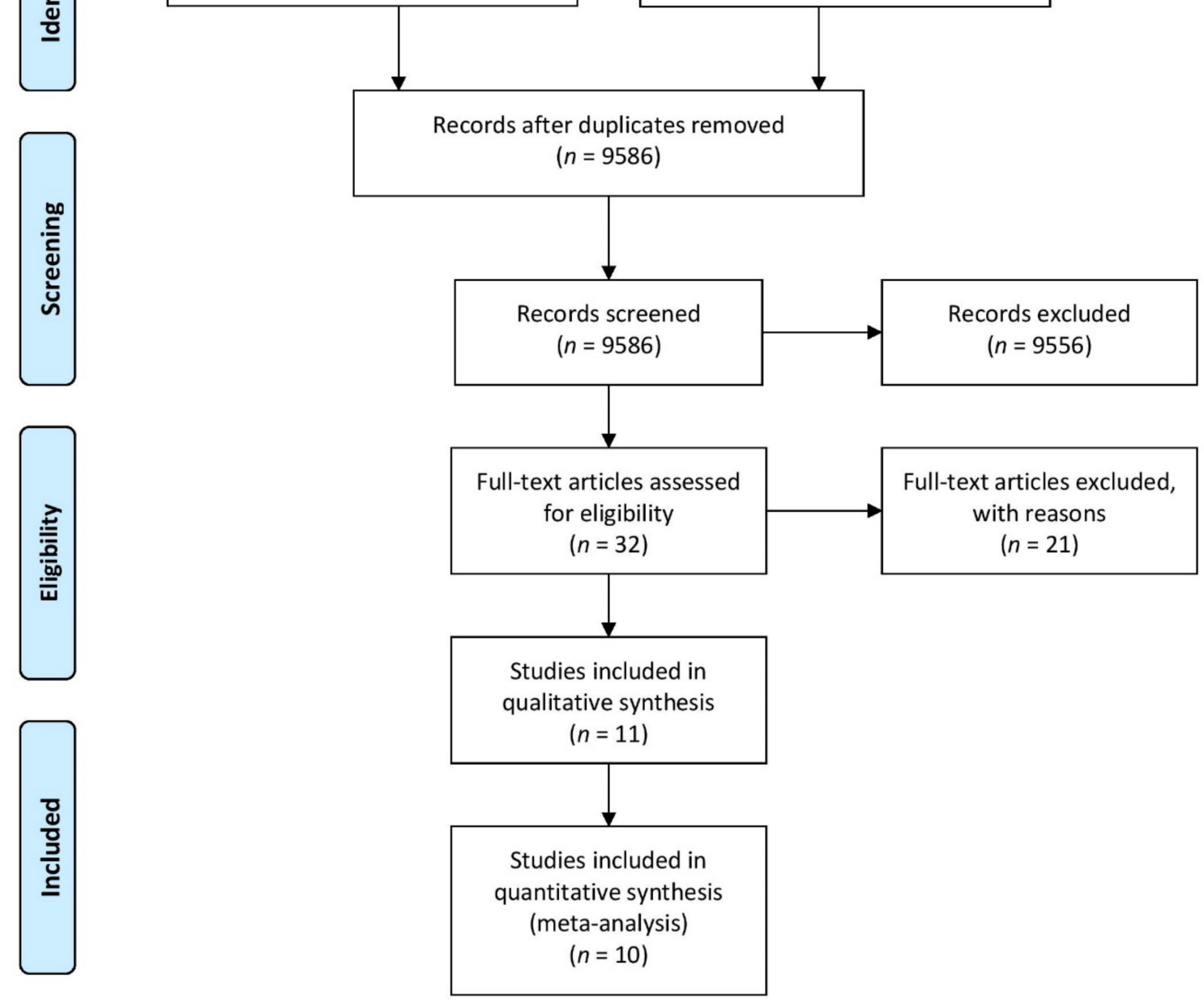

Figure 1. Preferred Reporting Items for Systematic Reviews and Meta-Analyses (PRISMA) flow diagram.

\subsection{Characteristics of the Included Studies for Qualitative Synthesis}

Regarding the geographic localization of the studies, five studies were conducted in European countries, four were conducted in Near East countries, and two were conducted in the USA. Six studies were performed exclusively in patients with focal epilepsy $[10,15-17,19,20]$, with two of them conducted on patients with temporal lobe epilepsy [10,17]. Two studies were performed in cohorts of patients with drug-resistant epilepsy exclusively $[14,20]$. Also, the cohort in Iorio et al. [11] that was selected for our analysis consisted of only drug-resistant epilepsy patients.

All studies were cross-sectional except for the study by Iorio et al. [11], which had an observational prospective design. Only five studies had a control group, consisting of 
healthy subjects $[11,13,15,16]$ and patients with neurological diseases other than epilepsy and autoimmune diseases [12]. The results of the control group in Iorio et al. [11] are not presented in the article.

None of the selected studies were performed exclusively in cohorts of patients with new-onset epilepsy or hippocampal sclerosis. All studies tested autoantibodies in serum, but none performed a systematic determination in CSF. In Bruijn et al. [19], Iorio et al. [11], and Falip et al. [17], CSF antibodies were determined only in some patients with a viable sample, and in Liimatainen et al. [13] CSF antibodies were determined only in patients with a positive result in serum. Anti-GAD was the most frequently tested autoantibody, and it was determined in all studies, mainly by RIA, but more recent studies used IF as screening instead, and then other methods for confirmation and titers. Neural surface autoantibodies were tested in eight studies. In these studies, the most frequently determined were NMDAR and LGI1, which were tested in all of the studies. There was variability in the frequency of determination of CASPR2, GABAB, AMPAR, and GlyR between the different studies. GABAA was only determined in one study. IF was used for the determination of this type of autoantibodies. In the included studies, two strategies were used: one consisting of screening by IF IHC and then confirmation by CBA, and the other by performing CBA from the beginning. Onconeural antibodies were tested in six studies, in half of them in two steps, first IF IHC and then confirmation by immunoblot/CBA, but in the rest, only CBA or immunoblot was performed (Table 1).

Table 1. Number of patients and antibody determination method of the included studies. AMPAR: amino-3-hydroxy-5methyl-4-isoxazolepropionic acid receptor; CASPR2: contactin-2-associated protein; CBA: cell-based assay; GAD: glutamic acid decarboxylase; GlyR: glycine receptor; IHC: Immunohistochemistry; IRMA: immunoradiometric assay; LGI1: leucinerich glioma inactivated-1 protein; NMDAR: N-methyl-D-aspartate receptor; RIA: radioimmunoassay. ${ }^{*}$ not included in the meta-analysis.

\begin{tabular}{|c|c|c|c|c|c|}
\hline Reference & $\begin{array}{c}n \text { Patients } \\
\text { Included for } \\
\text { Meta-Analysis }\end{array}$ & Anti-GAD & $\begin{array}{l}\text { Neural Surface } \\
\text { Autoantibodies }\end{array}$ & Onconeuronal & Level of Evidence \\
\hline $\begin{array}{c}\text { Ansari B. et al., } \\
2019 \text { [10] * }\end{array}$ & $\begin{array}{c}N=33 \\
\text { Control group: } \\
\text { No }\end{array}$ & IF (CBA) & $\begin{array}{c}\text { IF (CBA): } \\
\text { NDMAR, AMPAR, LGI1, } \\
\text { CASPR2, GABA }_{\mathrm{B}}, \text { GlyR }\end{array}$ & IF (CBA) & $2-$ \\
\hline $\begin{array}{l}\text { Iorio R. et al., } \\
2015 \text { [11] }\end{array}$ & $\begin{array}{c}\quad N=42 \\
\text { Control group: } \\
\quad N=75\end{array}$ & RIA & $\begin{array}{l}\text { IF (IHC). Confirmed by } \\
\text { CBA } \\
\text { NMDAR, AMPAR, LGI1, } \\
\text { CASPR2, GABA },\end{array}$ & $\begin{array}{l}\text { IF (IHC). } \\
\text { Confirmed by } \\
\text { immunoblot }\end{array}$ & $2+$ \\
\hline $\begin{array}{c}\text { Brenner T. et al., } \\
2013 \text { [12] }\end{array}$ & $\begin{array}{c}N=176 \\
\text { Control group: } \\
N=148\end{array}$ & RIA & $\begin{array}{c}\text { IF (CBA) } \\
\text { NDMAR, LGI1, } \\
\text { CASPR2, GLYR }\end{array}$ & - & $2+$ \\
\hline $\begin{array}{l}\text { Liimatainen S. } \\
\text { et al., } 2010 \text { [13] }\end{array}$ & $\begin{array}{c}N=73 \\
\text { Control group: } \\
N=200\end{array}$ & $\begin{array}{l}\text { RIA. Confirmation } \\
\text { by IF/immunoblot }\end{array}$ & - & - & $2++$ \\
\hline $\begin{array}{l}\text { Teceilloglu M. } \\
\text { et al., } 2018 \text { [14] }\end{array}$ & $\begin{array}{c}N=77 \\
\text { Control group: } \\
\text { No }\end{array}$ & IRMA & - & Immunoblot & $2+$ \\
\hline $\begin{array}{l}\text { Gozubatik-Celik G. } \\
\text { et al., } 2017 \text { [15] }\end{array}$ & $\begin{array}{c}N=94 \\
\text { Control group: } \\
N=50\end{array}$ & RIA & $\begin{array}{c}\text { IF (CBA): } \\
\text { NMDAR, AMPAR, LGI1, } \\
\text { CASPR2, GABA }\end{array}$ & - & $2+$ \\
\hline $\begin{array}{c}\text { Ekizoglu E. et al., } \\
2014 \text { [16] }\end{array}$ & $\begin{array}{c}\quad N=81 \\
\text { Control group: } \\
\quad N=30\end{array}$ & IPA & $\begin{array}{c}\text { IF (CBA): } \\
\text { NMDAR, AMPAR, LGI1, } \\
\text { CASPR2, GlyR }\end{array}$ & - & $2++$ \\
\hline $\begin{array}{l}\text { Falip M. et al., } \\
2012 \text { [17] }\end{array}$ & $\begin{array}{c}N=23 \\
\text { Control group: } \\
\text { No }\end{array}$ & IF (IHC) and RIA & - & - & $2+$ \\
\hline
\end{tabular}


Table 1. Cont.

\begin{tabular}{|c|c|c|c|c|c|}
\hline Reference & $\begin{array}{c}n \text { Patients } \\
\text { Included for } \\
\text { Meta-Analysis }\end{array}$ & Anti-GAD & $\begin{array}{l}\text { Neural Surface } \\
\text { Autoantibodies }\end{array}$ & Onconeuronal & Level of Evidence \\
\hline $\begin{array}{l}\text { Dubey D. et al., } \\
2017 \text { [18] }\end{array}$ & $\begin{array}{c}\quad N=112 \\
\text { Control group: } \\
\text { No }\end{array}$ & RIA & $\begin{array}{c}\text { Method not specified: } \\
\text { NMDAR, AMPAR, LGI1, } \\
\text { GABA }_{B}\end{array}$ & $\begin{array}{l}\text { Method not } \\
\text { specified }\end{array}$ & $2+$ \\
\hline $\begin{array}{l}\text { de Bruijn MAAM } \\
\text { et al., } 2021 \text { [19] }\end{array}$ & $\begin{array}{c}N=582 \\
\text { Control group: } \\
\text { No }\end{array}$ & $\begin{array}{l}\text { IF (IHC). } \\
\text { Confirmation by } \\
\text { CBA and ELISA }\end{array}$ & $\begin{array}{l}\text { IF (IHC). Confirmation } \\
\text { and GlyR by CBA } \\
\text { NMDAR, AMPAR, LGI1, } \\
\text { CASPR2, GABA }_{B}, \\
\text { GABA }_{A}, \text { GlyR }\end{array}$ & $\begin{array}{l}\text { IF (IHC). } \\
\text { Confirmation by } \\
\text { immunoblot }\end{array}$ & $2++$ \\
\hline $\begin{array}{l}\text { Li Y. et al., } \\
2021 \text { [20] }\end{array}$ & $\begin{array}{c}N=42 \\
\text { Control group: } \\
\text { No }\end{array}$ & $\begin{array}{l}\text { IF (IHC or CBA). } \\
\text { Confirmation by } \\
\text { other techniques }\end{array}$ & $\begin{array}{c}\text { IF (IHC or CBA). } \\
\text { Confirmation by other } \\
\text { techniques } \\
\text { NMDAR, AMPAR, LGI1, } \\
\text { CASPR2, GABA } \mathrm{B}\end{array}$ & $\begin{array}{l}\text { IF (IHC or CBA). } \\
\text { Confirmation by } \\
\text { other techniques }\end{array}$ & $2+$ \\
\hline
\end{tabular}

\subsection{Neural Autoantibodies Pooled Prevalence}

Ten studies were included for the global pooled prevalence meta-analysis after excluding Ansari et al. [9] by sensitivity analysis. The global pooled prevalence (IC95\%) was 7.6\% (4.6-11.2), with a total of 82 patients with epilepsy of unknown etiology with a positive result for any neural autoantibody (Figure 2). The prevalence in the different studies varied from $1.2 \%$ in the study of Tecellioglu et al. [14] to $14.2 \%$ in Li et al. [20] and Iorio et al. [11]. None of the 428 controls had a positive result.

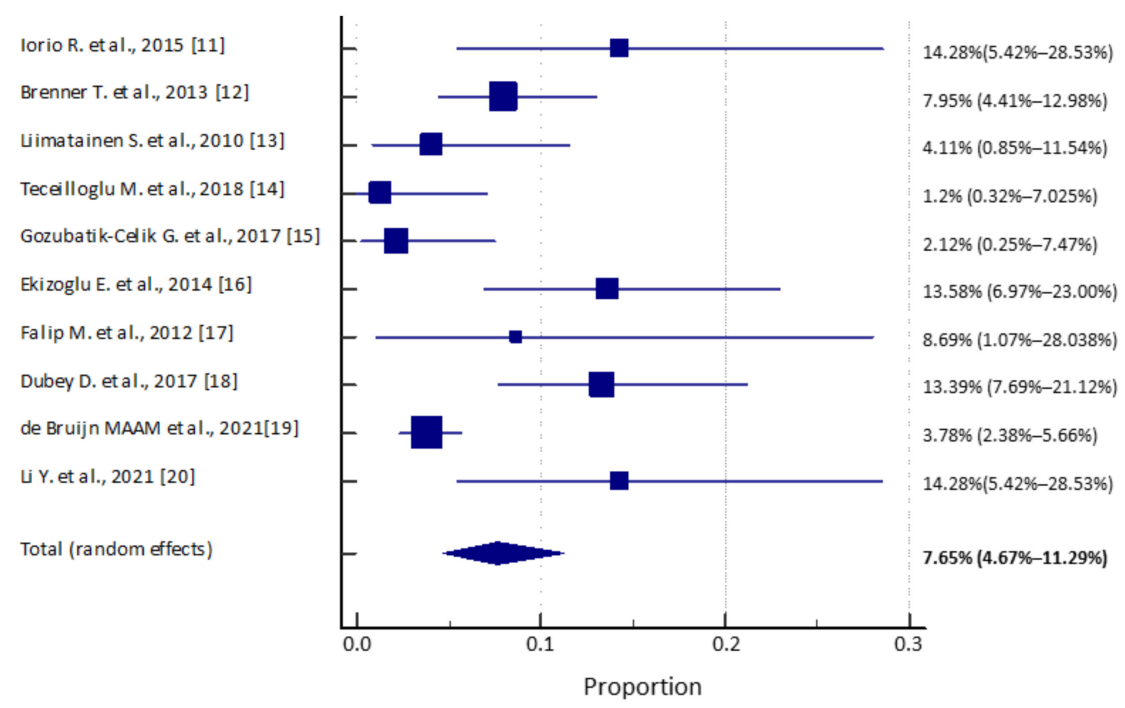

Figure 2. Pooled prevalence forest plot [11-20].

Nine studies were included in the meta-analysis for individual pooled prevalence for each autoantibody. The study of $\mathrm{Li}$ et al. [20] was excluded, as it was not possible to individually extract the data from the prospective cohort (see Supplementary Table S1). In descending order, the prevalence for each autoantibody was as follows: GlyR (3.2\%), GAD $(1.9 \%)$, NMDAR $(1.8 \%)$, LGI1 $(1.0 \%)$, CASPR2 $(0.6 \%)$, and onconeural antibodies $(0.2 \%)$. Positive results for onconeuronal autoantibodies consisted of one patient for anti-Hu and another for Ma2/TA. In the studies with CSF available from some patients, only one patient harbored a positive result (NMDAR) in CSF but was negative in serum [19]. Table 2 shows 
the global and individual pooled prevalence with a $95 \% \mathrm{CI}$, as well as the number of studies and patients included in the analysis.

Table 2. The estimated pooled prevalence, the $95 \%$ confidence interval (CI), number of included studies and subjects, I2 as a measure for heterogeneity, $p$-value of the Egger's test, and percentage of studies with low risk of bias for all meta-analyses.

\begin{tabular}{ccccccccc}
\hline $\begin{array}{c}\text { Neural Au- } \\
\text { toantibody }\end{array}$ & $\begin{array}{c}\boldsymbol{n} \text { Studies } \\
\text { Deter- } \\
\text { mined }\end{array}$ & $\begin{array}{c}n \text { Subjects } \\
\text { Deter- } \\
\text { mined }\end{array}$ & $\begin{array}{c}\text { Pooled } \\
\text { Prevalence }\end{array}$ & CI Lower & CI Upper & I-Squared & $\begin{array}{c}p \text {-Value } \\
\text { Egger's } \\
\text { Test }\end{array}$ & $\begin{array}{c}p \text {-Value } \\
\text { Begg's Test }\end{array}$ \\
\hline Total & 11 & 1302 & $7.6 \%$ & $4.6 \%$ & $11.2 \%$ & $75 \%$ & 0.11 & 0.58 \\
\hline GlyR & 3 & 839 & $3.2 \%$ & $0.1 \%$ & $9.8 \%$ & $91 \%$ & 0.20 & 0.60 \\
\hline GAD & 9 & 1260 & $1.9 \%$ & $0.6 \%$ & $3.8 \%$ & $70 \%$ & 0.76 & 0.14 \\
\hline NMDAR & 7 & 1129 & $1.8 \%$ & $0.6 \%$ & $3.7 \%$ & $66 \%$ & 0.08 & 0.75 \\
\hline LGI1 & 6 & 1087 & $1.0 \%$ & $0.2 \%$ & $2.7 \%$ & $68 \%$ & 0.36 & 0.09 \\
\hline CASPR2 & 6 & 1017 & $0.6 \%$ & $0.2 \%$ & $1.3 \%$ & $47 \%$ & 0.65 & 0.22 \\
\hline Onconeuronal & 5 & 855 & $0.2 \%$ & $0.1 \%$ & $0.8 \%$ & $38 \%$ & 0.10 \\
\hline
\end{tabular}

\subsection{Heterogeneity and Publication Bias Assessment}

The total cohort showed substantial heterogeneity (I $2>50 \%$ ). The value of I2 to measure the heterogeneity of the global sample and for each antibody is shown in Table 2. The study of Ansari et al. [9] was excluded by sensitivity analysis. The Egger's and Begg's tests were used to evaluate publication bias in this meta-analysis. The bias was found to be statistically insignificant for the total cohort and for each antibody (Table 2).

\section{Discussion}

In this study, we attempted to estimate the pooled prevalence of neural autoantibodies in patients 16 years or older with epilepsy of unknown etiology through a systematic review of the literature and a meta-analysis. Our results show a pooled prevalence of 7.6\% (IC95, 4.6-11.2\%) in patients with epilepsy of unknown etiology. This suggests a possible immunemediated mechanism in a low but not negligible proportion of patients with epilepsy of supposed unknown etiology and therefore the opportunity for a targeted treatment. It should be noted that this differs from the results of a different clinical scenario, which is the frequency of epileptic seizures in autoimmune encephalitis, where the prevalence is high [28].

The prevalence between studies varied from $1.2 \%$ in Tecellioglu et al. [14] and 14.28\% in Iorio et al. [11] and Li et al. [20]. Interestingly, these three studies were performed in drug-resistant patients, a characteristic favoring a possible autoimmune origin [18,19]. The relatively low prevalence in Tecellioglu et al. was probable due to the methodology. In this study, the authors determined GAD65 by IRMA, being the only study included that used this method. We cannot say at the moment that immunoradiometric assay (IRMA) is less sensitive than RIA, but studies in other ambits found differences in the results of both methods [29]. Nevertheless, the comparatively low prevalence in this study can be explained because only testing for onconeuronals and anti-GAD and VGKC neural autoantibodies was performed. Some patients in this study were positive for VGKC but LGI1/CASPR2 were not tested, and hence we did not include them as a positive result. Determination of specific neural surface autoantibodies in this study could have increased the prevalence of positive results. Differences in prevalence were also found between the rest of the studies included in the meta-analysis, and the different methodologies and criteria for patient selection could also be a reason for this. For example, one of the studies with lower prevalence was the one from Bruijn et al. [19], where the included patients could not be suspicious of autoimmune etiology. In order to homogenize the sample 
for the analysis, we excluded studies with retrospective recruitment, where suspicion of autoimmune etiology is high.

In this systematic review, we also found high variability in the methodology for detecting neural autoantibodies among the included studies as well as which autoantibodies were considered for testing. We observed a great difference regarding the techniques used in the studies included to analyze GAD antibodies, and also in the titers that were considered high or very high (see Supplementary Table S1). Concerning neural surface autoantibodies, although the majority of the studies tested them by IF, some performed IHC first and then confirmed by CBA while others only performed CBA. In addition, the interpretation of what is a positive result by IF was variable between studies. For example, only some studies required confirmation by a second technique for certain autoantibodies $[11,13,19,20]$, others excluded weak positive results and used higher dilution ratio in order to consider them positive $[12,15,16]$, whereas Ansari et al. [10], which was excluded for meta-analysis by sensitivity analysis, considered weak positive results as positive, even with low dilution ratios, which could explain why it is the study with the highest pooled prevalence. In order to avoid pitfalls in the interpretation of neural antibodies results, it is advisable to perform panel testing of multiple autoantibodies rather than single antibody testing, screen both CSF and serum, and discuss cases with reference centers if antibodies directed to surface antigens are found at low titers in serum only, or if results do not match with the clinical presentation [30]. In recent studies in patients with epilepsy of suspected autoimmune etiology [31,32] where CSF analysis was systematically performed, only one patient had a positive result in CSF and was negative in serum [31]. Instead, eight patients had a positive result in serum but were not positive in CSF. Despite this, testing both CSF and serum in patients with suspected autoimmune encephalitis is essential [33], and hence should be also performed in clinical practice and future studiesof patients with epilepsy of suspected autoimmune etiology. Also, caution should be exercised when interpreting the results of commercial kits for onconeural antibodies because high frequency of false positive results and it is advisable to confirm positivity with at least two distinct techniques [34]. In future studies regarding neural autoantibody determination, it would be advisable to apply standardized methods $[24,35,36]$ in order to achieve more homogenous results between studies.

None of the controls presented a positive result, regardless of whether some had other immune or neurological diseases. Despite most of the studies not having a control group, the above suggests that neural autoantibodies may play a role in the epilepsy of these patients. However, neural autoantibodies can also be found, albeit in a smaller proportions, in patients with epilepsy of other defined etiologies [12]. Additionally, some seropositive patients with epilepsy achieve a long-term outcome without the need of immunotherapy $[9,37]$, so the mere presence of neural autoantibodies would not be enough to confirm a direct immune-mediated mechanism.

Regarding the pooled prevalence for each individual neural autoantibody, those with the highest pooled prevalence were GlyR, followed by GAD, NMDAR, and LGI1, with a high heterogeneity between studies. The prevalence for CASPR2 and onconeuronal autoantibodies was homogenous but with a lower frequency. Only one patient had a positive result for AMPAR, and none had a positive result for GABAB, suggesting that determining these antibodies in patients with epilepsy without other data suggestive of encephalitis is improbable, and that if detected, it is unlikely to have relevant significance. Instead, in view of the results, GlyR antibodies should be taken into account in future studies regarding immune epilepsies. These antibodies have been associated exclusively with long-term seizures without any other neurological symptom [38], with a better response to antiepileptic drugs, compared with other immune-based epilepsies [39], and with a response to immunotherapy in drug-resistant cases [40]. However, the high heterogeneity of their prevalence between studies makes it advisable to confirm results in future studies, with the drawback that testing for these antibodies can only be performed by a few laboratories. After GlyR, GAD was the most prevalent autoantibody in our analysis. This 
is not strange since, contrary to most neural autoantibodies, GAD antibodies have been associated for many years with drug-resistant epilepsies without meeting criteria of limbic encephalitis $[4,6,25]$, which is congruent with the selection criteria of our study. The relatively high prevalence of NMDAR antibodies among other neural surface autoantibodies could be explained by the fact that NMDAR encephalitis is the most frequent autoimmune encephalitis [41]. Epileptic seizures can be the first symptom of many in NMDAR encephalitis [42], and in a few patients, it may be its only clinical expression [41,42]. However, in addition to the heterogeneity in the results, it should be taken into account that false positives and negatives of this antibody are not uncommon when performed in serum [43]. Our data also show that $1 \%$ of patients with epilepsy of unknown etiology can suffer from LGI1 encephalitis. Although this entity usually courses with typical features [44], with some even considered pathognomonic [45], epilepsy can be the presenting symptom, and memory and behavior alterations may be subtle or can be attributed to other causes [19]. Related to the previous point, is important to underlie that cognitive impairment is one of the classic manifestations of limbic encephalitis and sometimes is the predominant symptom (autoantibody-associated cognitive impairment) [46]. In patients with epilepsy of unknown etiology, a systematic cognitive exam revealing not only impaired working memory or short-term memory but also long-term memory formation may give us reason to suspect that there is an underlying autoimmune mechanism [47]. This could compensate for the lack of sensitivity in detecting subtle autoimmune encephalitis with actual criteria [33].

Our study presents some limitations. First, as occurs in many meta-analyses, there is heterogeneity between the results of the included studies due to small sample sizes and the variability in methodology and patient selection. To homogenize patients, we excluded studies with retrospective recruitment, studies performed exclusively in patients with high suspicion of autoimmune etiology, prior testing, or those in pre-selected epilepsy cohorts. An exception to the latter was the studies performed in drug-resistant epilepsy, hippocampal sclerosis, or new-onset epilepsy. The reason for this is that although these characteristics have been associated with autoimmune etiology, they are not specific if isolated $[9,19]$. These patients may be among those who benefit the most in routine clinical practice from the detection of a possible autoimmune mechanism. Second, in some studies the complementary exams to achieve the diagnosis of epilepsy of unknown etiology (i.e., high resolution MRI or long-term video-EEG) are not specified, and in others $1.5 \mathrm{~T}$ scanner was the exam performed, so it is possible that some patients included actually had a subtle structural or an idiopathic etiology. Nevertheless, we revisited with detail all papers and we excluded studies were the diagnosis of epilepsy of unknown etiology was doubtful (see Supplementary Table S2). Third, very few studies had control groups. Finally, the possibility of some of these patients having antibodies not yet unidentified should be considered.

In conclusion, the pooled prevalence of neural autoantibodies in patients with epilepsy of unknown etiology is small but not irrelevant. Even though the presence of these autoantibodies does not strictly imply an immune-mediated mechanism in all cases, the absence of these autoantibodies in controls favor this possibility and therefore the chance of a targeted treatment for some patients. The prevalence for each antibody obtained in our review and meta-analysis can guide research in terms of which autoantibodies may be determined in future studies as well as on clinical grounds. Heterogeneity in the type of antibody and in the method for its determination is high among studies. Further studies with homogeneous neural autoantibody testing protocols are needed in order to get a more accurate result of the actual prevalence of neural autoantibodies and also to find other parameters in order to improve the current understanding of the clinical significance of neuronal autoantibodies in patients with epilepsy of unknown origin.

Supplementary Materials: The following are available online at https:/ / www.mdpi.com/2076-342 5/11/3/392/s1: Supplementary Table S1: Data extraction sheet; Supplementary Table S2: Excluded studies and their reason. 
Author Contributions: Conceptualization: P.C.-G. and N.M.-V.; methodology: P.C.-G., N.M.-V., and G.E.-T.; formal analysis: P.C.-G. and N.M.-V.; writing-original draft preparation: P.C.-G., N.M.V., and N.L.C.-P.; writing-review and editing: P.C.-G., N.M.-V., N.L.C.-P., G.G.-M., and G.E.-T.; supervision: P.J.S.-C. All authors have read and agreed to the published version of the manuscript.

Funding: Grant for medical Research. Fundación Española de Reumatología. N.M.-V.

Institutional Review Board Statement: Not applicable.

Informed Consent Statement: Not applicable.

Conflicts of Interest: The authors declare no conflict of interest influencing the representation or interpretation of the reported research results.

\section{References}

1. Spatola, M.; Novy, J.; Du Pasquier, R.; Dalmau, J.; Rossetti, A.O. Status epilepticus of inflammatory etiology. Neurology 2015, 85, 464-470. [CrossRef] [PubMed]

2. Geis, C.; Planagumà, J.; Carreño, M.; Graus, F.; Dalmau, J. Autoimmune seizures and epilepsy. J. Clin. Investig. 2019, 129, 926-940. [CrossRef] [PubMed]

3. Scheffer, I.E.; Berkovic, S.; Capovilla, G.; Connolly, M.B.; French, J.; Guilhoto, L.; Hirsch, E.; Jain, S.; Mathern, G.W.; Moshé, S.L.; et al. ILAE classification of the epilepsies: Position paper of the ILAE Commission for Classification and Terminology. Epilepsia 2017, 58, 512-521. [CrossRef] [PubMed]

4. Husari, K.S.; Dubey, D. Autoimmune Epilepsy. Neurother. J. Am. Soc. Exp. Neurother. 2019, 16, 685-702.

5. Fisher, R.S.; Acevedo, C.; Arzimanoglou, A.; Bogacz, A.; Cross, J.H.; Elger, C.E.; Engel, J.; Forsgren, L.; French, J.A.; Glynn, M.; et al. ILAE Official Report: A practical clinical definition of epilepsy. Epilepsia 2014, 55, 475-482. [CrossRef] [PubMed]

6. Steriade, C.; Britton, J.; Dale, R.C.; Gadoth, A.; Irani, S.R.; Linnoila, J.; McKeon, A.; Shao, X.; Venegas, V.; Bien, C.G. Acute symptomatic seizures secondary to autoimmune encephalitis and autoimmune-associated epilepsy: Conceptual definitions. Epilepsia 2020, 61, 1341-1351. [CrossRef]

7. Rada, A.; Birnbacher, R.; Gobbi, C.; Kurthen, M.; Ludolph, A.; Naumann, M.; Neirich, U.; von Oertzen, T.J.; Ransmayr, G.; Riepe, M.; et al. Seizures associated with antibodies against cell surface antigens are acute symptomatic and not indicative of epilepsy: Insights from long-term data. J. Neurol. 2021, 268, 1059-1069. [CrossRef] [PubMed]

8. Hansen, N.; Ernst, L.; Rüber, T.; Widman, G.; Becker, A.J.; Elger, C.E.; Helmstaedter, C. Pre- and long-term postoperative courses of hippocampus-associated memory impairment in epilepsy patients with antibody-associated limbic encephalitis and selective amygdalohippocampectomy. Epilepsy Behav. 2018, 79, 93-99. [CrossRef]

9. McGinty, R.N.; Handel, A.; Moloney, T.; Ramesh, A.; Fower, A.; Torzillo, E.; Kramer, H.; Howell, S.; Waters, P.; Adcock, J.; et al. Clinical features which predict neuronal surface autoantibodies in new-onset focal epilepsy: Implications for immunotherapies. J. Neurol. Neurosurg. Psychiatry 2021, 92, 291-294. [CrossRef]

10. Ansari, B.; Etemadifar, M.; Najafi, M.; Nasri, M.; Meamar, R. Neuronal autoantibodies in focal epilepsy with or without mesial temporal sclerosis. Iran. J. Neurol. 2019, 18, 13-18. [CrossRef]

11. Iorio, R.; Assenza, G.; Tombini, M.; Colicchio, G.; Della Marca, G.; Benvenga, A.; Damato, V.; Rossini, P.M.; Vollono, C.; Plantone, D.; et al. The detection of neural autoantibodies in patients with antiepileptic-drug-resistant epilepsy predicts response to immunotherapy. Eur. J. Neurol. 2015, 22, 70-78. [CrossRef] [PubMed]

12. Brenner, T.; Sills, G.J.; Hart, Y.; Howell, S.; Waters, P.; Brodie, M.J.; Vincent, A.; Lang, B. Prevalence of neurologic autoantibodies in cohorts of patients with new and established epilepsy. Epilepsia 2013, 54, 1028-1035. [CrossRef] [PubMed]

13. Liimatainen, S.; Peltola, M.; Sabater, L.; Fallah, M.; Kharazmi, E.; Haapala, A.-M.; Dastidar, P.; Knip, M.; Saiz, A.; Peltola, J. Clinical significance of glutamic acid decarboxylase antibodies in patients with epilepsy. Epilepsia 2010, 51, 760-767. [CrossRef] [PubMed]

14. Tecellioglu, M.; Kamisli, O.; Kamisli, S.; Yucel, F.E.; Ozcan, C. Neurological autoantibodies in drug-resistant epilepsy of unknown cause. Ir. J. Med. Sci. 2018, 187, 1057-1063. [CrossRef]

15. Gozubatik-Celik, G.; Ozkara, C.; Ulusoy, C.; Gunduz, A.; Delil, S.; Yeni, N.; Tuzun, E. Anti-Neuronal Autoantibodies in Both Drug Responsive and Resistant Focal Seizures with Unknown Cause. Epilepsy Res. 2017, 135, 131-136. [CrossRef]

16. Ekizoglu, E.; Tuzun, E.; Woodhall, M.; Lang, B.; Jacobson, L.; Icoz, S.; Bebek, N.; Gurses, C.; Gokyigit, A.; Waters, P.; et al. Investigation of neuronal autoantibodies in two different focal epilepsy syndromes. Epilepsia 2014, 55, 414-422. [CrossRef] [PubMed]

17. Falip, M.; Carreno, M.; Miró, J.; Saiz, A.; Villanueva, V.; Quílez, A.; Molins, A.; Barceló, I.; Sierra, A.; Graus, F. Prevalence and immunological spectrum of temporal lobe epilepsy with glutamic acid decarboxylase antibodies. Eur. J. Neurol. 2012, 19, 827-833. [CrossRef]

18. Dubey, D.; Alqallaf, A.; Hays, R.; Freeman, M.; Chen, K.; Ding, K.; Agostini, M.; Vernino, S. Neurological Autoantibody Prevalence in Epilepsy of Unknown Etiology. JAMA Neurol. 2017, 74, 397-402. [CrossRef]

19. De Bruijn, M.A.; Bastiaansen, A.E.; Mojzisova, H.; van Sonderen, A.; Thijs, R.D.; Majoie, M.J.; Rouhl, R.P.; van CoevordenHameete, M.H.; de Vries, J.M.; Lopetegi, A.M.; et al. The Antibodies Contributing to focal Epilepsy Signs and symptoms (ACES) score. Ann. Neurol. 2021. [CrossRef] 
20. Li, Y.; Tymchuk, S.; Barry, J.; Muppidi, S.; Le, S. Antibody Prevalence in Epilepsy before Surgery (APES) in drug-resistant focal epilepsy. Epilepsia 2021, 1-9. [CrossRef]

21. Moher, D.; Liberati, A.; Tetzlaff, J.; Altman, D.G. Preferred reporting items for systematic reviews and meta-analyses: The PRISMA statement. PLoS Med. 2009, 6, e1000097. [CrossRef] [PubMed]

22. Pleasure, D. Diagnostic and Pathogenic Significance of Glutamate Receptor Autoantibodies. Arch. Neurol. 2008, 65, 589-592. [CrossRef]

23. Michael, S.; Waters, P.; Irani, S.R. Stop testing for autoantibodies to the VGKC-complex: Only request LGI1 and CASPR2. Pract. Neurol. 2020, 20, 377-384. [CrossRef] [PubMed]

24. Muñoz-Lopetegi, A.; de Bruijn, M.A.; Boukhrissi, S.; Bastiaansen, A.E.; Nagtzaam, M.M.; Hulsenboom, E.S.; Boon, A.J.; Neuteboom, R.F.; de Vries, J.M.; Smitt, P.A.S.; et al. Neurologic syndromes related to anti-GAD65: Clinical and serologic response to treatment. Neurol. Neuroimmunol. Neuroinflammat. 2020, 7, e696. [CrossRef] [PubMed]

25. Graus, F.; Saiz, A.; Dalmau, J. GAD antibodies in neurological disorders-Insights and challenges. Nat. Rev. Neurol. 2020, 16, 353-365. [CrossRef] [PubMed]

26. Miller, J. The Scottish Intercollegiate Guidelines Network (SIGN). Br. J. Diabetes Vasc. Dis. 2002, 2, 47-49. [CrossRef]

27. Higgins, J.P.; Thomas, J.; Chandler, J.; Cumpston, M.; Li, T.; Page, M.J.; Welch, V.A. Updated Guidance for Trusted Systematic Reviews: A New Edition of the Cochrane Handbook for Systematic Reviews of Interventions; The Cochrane Database of Systematic Reviews; John Wiley \& Sons: Oxford, UK, 2019; Volume 10, p. ED000142.

28. Yeshokumar, A.K.; Coughlin, A.; Fastman, J.; Psaila, K.; Harmon, M.; Randell, T.; Schorr, E.M.; Han, H.; Hoang, H.; Soudant, C.; et al. Seizures in autoimmune encephalitis-A systematic review and quantitative synthesis. Epilepsia 2021, 62, 397-407. [CrossRef]

29. Stanojevic, M.; Savin, S.; Cvejic, D.; Djukic, A.; Jeremic, M.; Simonovic, S.Z. Comparison of the influence of thyroglobulin antibodies on serum thyroglobulin values from two different immunoassays in post surgical differentiated thyroid carcinoma patients. J. Clin. Lab. Anal. 2009, 23, 341-346. [CrossRef]

30. Vogrig, A.; Joubert, B.; André-Obadia, N.; Gigli, G.L.; Rheims, S.; Honnorat, J. Seizure specificities in patients with antibodymediated autoimmune encephalitis. Epilepsia 2019, 60, 1508-1525. [CrossRef]

31. Kuehn, J.C.; Meschede, C.; Helmstaedter, C.; Surges, R.; Von Wrede, R.; Hattingen, E.; Vatter, H.; Elger, C.E.; Schoch, S.; Becker, A.J.; et al. Adult-onset temporal lobe epilepsy suspicious for autoimmune pathogenesis: Autoantibody prevalence and clinical correlates. PLoS ONE 2020, 29, e0241289. [CrossRef]

32. Bozzetti, S.; Rossini, F.; Ferrari, S.; Delogu, R.; Cantalupo, G.; Marchioretto, F.; Zanette, G.; Zanoni, T.; Turatti, M.; Vitale, G.; et al. Epileptic seizures of suspected autoimmune origin: A multicentre retrospective study. J. Neurol. Neurosurg. Psychiatry 2020, 91, 1-9. [CrossRef] [PubMed]

33. Graus, F.; Titulaer, M.J.; Balu, R.; Benseler, S.; Bien, C.G.; Cellucci, T.; Cortese, I.; Dale, R.C.; Gelfand, J.M.; Geschwind, M.; et al. A clinical approach to diagnosis of autoimmune encephalitis. Lancet Neurol. 2016, 15, 391-404. [CrossRef]

34. Déchelotte, B.; Muñiz-Castrillo, S.; Joubert, B.; Vogrig, A.; Picard, G.; Rogemond, V.; Pinto, A.-L.; Lombard, C.; Desestret, V.; Fabien, N.; et al. Diagnostic yield of commercial immunodots to diagnose paraneoplastic neurologic syndromes. Neurol. Neuroimmunol. Neuroinflamm. 2020, 7, e701. [CrossRef] [PubMed]

35. George, N.; Fotedar, N.; Abboud, H. Confounders in the Interpretation of Paraneoplastic and Neuronal Autoantibody Panels. Clin. Lab. Med. 2020, 40, 305-316. [CrossRef] [PubMed]

36. Ricken, G.; Schwaiger, C.; De Simoni, D.; Pichler, V.; Lang, J.; Glatter, S.; Macher, S.; Rommer, P.S.; Scholze, P.; Kubista, H.; et al. Detection Methods for Autoantibodies in Suspected Autoimmune Encephalitis. Front. Neurol. 2018, 9, 1-12. [CrossRef]

37. Rüegg, S. Antineuronal antibodies and epilepsy: Treat the patient, not the lab. J. Neurol. Neurosurg. Psychiatry 2021, $92,230$. [CrossRef]

38. Ekizoglu, E.; Baykan, B.; Sezgin, M.; Erdag, E.; Gundogdu-Unverengil, G.; Vanl1-Yavuz, E.N.; Tekturk, P.; Y1lmaz, E.; Bebek, N.; Tuzun, E. Follow-up of patients with epilepsy harboring antiglycine receptor antibodies. Epilepsy Behav. 2019, 92, $103-107$. [CrossRef]

39. Cabezudo-García, P.; Mena-Vázquez, N.; Villagrán-García, M.; Serrano-Castro, P.J. Efficacy of antiepileptic drugs in autoimmune epilepsy: A systematic review. Seizure 2018, 59, 72-76. [CrossRef]

40. Swayne, A.; Tjoa, L.; Broadley, S.; Dionisio, S.; Gillis, D.; Jacobson, L.; Woodhall, M.R.; McNabb, A.; Schweitzer, D.; Tsang, B.; et al. Antiglycine receptor antibody related disease: A case series and literature review. Eur. J. Neurol. 2018, 25, 1290-1298. [CrossRef]

41. Dalmau, J.; Graus, F. Antibody-Mediated Encephalitis. N. Engl. J. Med. 2018, 378, 840-851. [CrossRef]

42. Titulaer, M.J.; McCracken, L.; Gabilondo, I.; Armangué, T.; Glaser, C.; Iizuka, T.; Honig, L.S.; Benseler, S.M.; Kawachi, I.; MartinezHernandez, E.; et al. Treatment and prognostic factors for long-term outcome in patients with anti-NMDA receptor encephalitis: An observational cohort study. Lancet Neurol. 2013, 12, 157-165. [CrossRef]

43. Gresa-Arribas, N.; Titulaer, M.J.; Torrents, A.; Aguilar, E.; McCracken, L.; Leypoldt, F.; Gleichman, A.J.; Balice-Gordon, R.; Rosenfeld, M.R.; Lynch, D.; et al. Antibody titres at diagnosis and during follow-up of anti-NMDA receptor encephalitis: A retrospective study. Lancet Neurol. 2014, 13, 167-177. [CrossRef]

44. Van Sonderen, A.; Thijs, R.D.; Coenders, E.C.; Jiskoot, L.C.; Sanchez, E.; De Bruijn, M.A.; van Coevorden-Hameete, M.H.; Wirtz, P.W.; Schreurs, M.W.; Smitt, P.A.S.; et al. Anti-LGI1 encephalitis: Clinical syndrome and long-term follow-up. Neurology 2016, 84, 1449-1456. [CrossRef] [PubMed] 
45. Sen, A.; Wang, J.; Laue-Gizzi, H.; Lee, T.; Ghougassian, D.; Somerville, E.R. Pathognomonic seizures in limbic encephalitis associated with anti-LGI1 antibodies. Lancet 2014, 383, 2018. [CrossRef]

46. Hansen, N.; Malchow, B.; Zerr, I.; Stöcker, W.; Wiltfang, J.; Timäus, C. Neural cell-surface and intracellular autoantibodies in patients with cognitive impairment from a memory clinic cohort. J. Neural Transm. 2021, 1-13. [CrossRef] [PubMed]

47. Hansen, N. Long-Term Memory Dysfunction in Limbic Encephalitis. Front. Neurol. 2019, 10, 1-5. [CrossRef] [PubMed] 